JOURNAL Of

CONTEMPORARY INDONESIAN ART

Jurusan Seni Murni

FSR ISI Yogyakarta

ISSN: 2442-3394

E-ISSN: 2442-3637

\section{TRANSFORMASI MATERIAL KERTAS DALAM PENCIPTAAN KARYA SENI LUKIS}

\section{Oleh: Widi Pangestu Sugiono}

Institusi: Institut Seni Indonesia Yogyakarta

Jalan Parangtritis Km. 6,5 Sewon Yogyakarta

E-mail: pangestuwidi@gmail.com

\begin{abstract}
ABSTRAK
Seni dapat menjadi sebuah identitas yang mencakup persoalan personal, sosial maupun kultural. Pertanyaan-pertanyaan seputar seni adalah sebuah paham modernisme yang mempertanyakan "apa itu seni" yang dikenal juga sebagai filsafat seni atau estetika. Pertanyaan mendasar tersebut mengakibatkan dinamika sejarah seni untuk terus membuat manifesto jawaban yang kemudian dipertanyakan kembali. Dengan kata lain definisi seni dalam subjektifitas penulis adalah media antara nilai-nilai dalam kehidupan yang meliputi kode - kode estetika yang dapat berkaitan dengan konteks kultural lalu dikomunikasikan secara simultan yang dikemas sedemikian rupa menjadi sebuah karya seni. Karya seni memiliki otonomi artistiknya sendiri untuk menegaskan makna penting subjek seniman dalam menciptakan karya seni. Penulis menggunakan material kertas dengan proses mentransformasikan serat menjadi kertas yang memiliki bentuk baru, penggunaan kertas sebagai idiom berkarya bertujuan untuk memahami tentang relasi dan ekspansi medium, terutama pada perkembangan seni lukis.
\end{abstract}

Kata kunci: tranformasi material, kertas, lukis

\begin{abstract}
Art can be an identity that covers personal, social, and cultural issues. The question surrounding art is modernism which questions "what is art?", also known as the philosophy of art or aesthetics. This fundamental question resulted in the dynamics of art history to continue to make manifesto answers that were then questioned again. In other words, the definition of art in the subjectivity of the author is a medium between values in life that include codes aesthetic codes that can be related to the cultural context and then communicated simultaneously that are packaged in such a way as a work of art. The artwork has its artistic autonomy to affirm the important meaning of the subject of the artist in creating the artwork. The author utilizes paper as a material, with the process of transforming fiber into a new form of paper. The use of paper as a working idiom aims to understand the relationship and expansion of the medium, especially in the development of painting.
\end{abstract}

Keyword: material transformation, materiality, painting, paper 


\section{A. Pendahuluan}

Mcluhan (1994) dalam bukunya berjudul Understanding Media mengatakan bahwa medium merupakan pembawa pesan (medium is the message). Dengan demikian medium seni bagi perupa kontemporer umumnya tidak saja berfungsi sebagai medium spesifik dengan ciri-ciri kualitas estetiknya, namun juga sejarah perkembangan media itu sendiri dengan atribut nilai-nilai kontekstualnya digunakan oleh seniman untuk tujuantujuan praktis dan juga politis. Hal tersebut menunjukkan pergeseran konsep medium yang awalnya terfokus pada fungsi estetik dan artistik menjadi bentuk pengolahan pesan yang lebih luas, yaitu bagaimana pesan identitas kontekstual media menjadi kode simbolik media dan memberikan fungsi pendukung pesan seni yang meluas dan kompleks.

Dalam konteks seni rupa, media seni rupa yang merupakan sebuah entitas konvensi teknik dan material bukanlah merupakan sebuah wahana yang statis, namun media seni dengan segala atribut identitas kontekstualnya telah menjadi bagian terpenting bagi seniman. Setiap konvensi media membawa juga sejarah media dan kode-kode simbolik yang kini dimanfaatkan dan menjadi nilainilai baru dalam seni rupa kontemporer, sehingga membawa penulis melihat problem estetik paska-media fisik yang mengalami redefinisi dengan munculnya kecenderungan era media baru disebut sebagai seni kontemporer. Ini adalah pengalaman estetik dari bentuk-bentuk seni yang muncul secara simultan baik itu lukisan, patung instalasi maupun seniseni intermedia dan seni digital.

Perubahan tersebut mengalami demokratisasi khususnya terhadap perkembangan dan pemaknaan seni lukis dalam seni rupa kontemporer. Lukis sebagai bidang dapat diperkaya dan diperluas melalui tiga unsur; gagasan tentang keunikan atau reproduktivitas, sarana proyeksi ruang matematis, dan sejarah. Lukis sebagai medium pada dasarnya merupakan satu konsep yang universal. Prosesnya merupakan suatu bentuk aplikasi membubuhkan warna, pigmen atau cat pada satu bidang sehingga menjadi satu gambar. Dalam konteks seni, yang kemudian umum disebut seni lukis, merupakan istilah yang kemudian menjelaskan baik proses dan hasil lukisan, jika drawing sebagai media cenderung terlihat sisi immediacy dan kelugasan, lukisan adalah tahap lebih lanjut. Prosesnya menunjukkan dimensi media yang kompleks untuk menghasilkan gambar, dengan teknik-teknik tertentu yang menggabungkan unsur pigmen warna pada permukaan yang dilukis.

Konvensi yang paling umum sebagai salah satu ciri seni lukis adalah kain kanvas. Kain kanvas sebagai dasar bidang permukaan representasi gambar lukisan menjadi salah satu yang paling praktis, baik bagi profesional maupun amatir. Sifatnya yang mampu menjadi pengikat pigmen, kemudahan tersedianya beragam ukuran, serta fleksibilitasnya untuk direntang ataupun digulung, menjadi pilihan yang paling efektif. Hampir sepanjang zaman sejak kain kanvas pertama kali digunakan sebagai bidang lukisan, kain kanvas adalah konvensi yang paling bertahan sehingga lukisan di atas kanvas menjadi stereotype seni lukis.

Selain lukis ditinjau dari fungsi artistiknya bagi seniman, seni lukis modern sebagai cara merepresentasikan sebuah gambaran menjadi salah satu bentuk seni yang memberikan banyak kasus problem estetik dalam sejarah perkembangannya. Seni lukis menjadi salah satu pembanding bagi perkembangan media seni rupa lainnya. Misalnya seni lukis dibandingkan dengan drawing dalam sifat kedatarannya, dibandingkan dengan patung dalam sifat eksistensi gambaran bentuknya, dibandingkan dengan seni grafis dalam kemungkinan reproduksinya, bahkan seni lukis menjadi patokan bagi perkembangan seni itu sendiri.

Seiring perkembangannya tersebut sebagai penanda datangnya awal seni media baru-salah satu persepsi yang 
merupakan ciri khas seni abad ke-20 adalah kecenderungan kuatnya untuk terus menerus mempertanyakan tradisi lukis yang panjang sebagai medium representasi yang memiliki hak - hak istimewa. Di awal abad ke-20 ketetapan hati Braque dan Picasso untuk menggabungkan material sehari-hari ke dalam lukisan, seperti surat kabar, pinggiran taplak meja, atau tali, adalah ekspresi dari perjuangan mereka untuk memperluas muatan (content) kanvas di luar cat atau yang lebih dikenal dengan julukan 'struggle with the canvas'. Ini menandai cara para seniman abad ke-20, mulai dari seniman Rusia Malevich dan Tailim, sampai Pollock pada pertengahan abad, hingga pelukis seperti Ricard Prince yang menciptakan abstraksi melalui komputer sebelum melukiskannya di atas kanvas. Abstrak, surealisme dan konseptualisme, adalah beberapa bentuk seni abad ke-20 yang terlibat secara mendalam dalam mempertanyakan lukisan tradisional.

Persepsi ini, walaupun tepat dalam banyak hal, terlalu menyamaratakan dan tidak cukup memberi penjelasan mengenai keluasan praktek-praktek seni yang diperkenalkan di akhir abad tersebut. Ciri khas lainnya di masa itu tertuju pada sifat "eksperimental", para seniman mendobrak batas - batas lukis dan patung dalam banyak cara dan memasukan material material baru ke dalam karyanya. Seniman membubuhkan readymade atau potongan - potongan objek yang mempresentasikan keseharian.

Pergeseran fokus dari representasi objektif ke ekspresi personal dan membuka babak baru seni setelah deskripsi babak sejarah media seni memberikan identitas kontekstual pada setiap medium yang dapat menjadi pintu masuk seniman kontemporer, setelah konvensi medium estetik digugurkan oleh paradigma kultural baru yaitu demokratisasi pilihan medium untuk strategi permainan citraan dalam kompleksitas budaya visual.

Berdasarkan urain diatas, muncul beberapa hal yang menjadi permasalahan yang akan diuraikan dalam karya seni sebagai berikut:

1. Bagaimana transformasi material kertas dalam perkembangan dan perluasan makna atas media seni lukis?

2. Bagaimana kertas dapat dijadikan medium untuk bereksplorasi?

\section{B. Konsep Penciptaan}

Idiom seni rupa sebenarnya tidak benar-benar otonom dalam menentukan bagaimana ia seharusnya terlihat dan menyampaikan sesuatu gagasan atau maksud karena terkait dengan relasi pasangannya yang sejati, yaitu medium. Banyak pihak secara terbatas memahami makna medium hanya sebagai bahan atau material yang bersifat fisikal. Kemajuan perkembangan seni rupa sebenarnya secara fundamental telah menafsirkan medium sebagai suatu makna yang bersifat lain, yang tidak sama persis dengan penjelasan keadaannya yang bersifat konkret dan fisikal. Medium melalui perkembangan gagasan tentang seni telah menghasilkan cara khas untuk menyampaikan gugus makna, tumbuh melalui atau bahkan tentang dirinya sendiri. Perkembangan dari cara pemahaman ini menghasilkan gagasan mendasar soal medium sebagai alat bagi pengalaman dan komunikasi, menjadi semacam perangkat makna yang bersifat tertentu dalam praktek seni rupa secara institusional maupun historis. Medium dalam hal ini berlaku sebagai habitat bagi berbagai idiom ekspresi baik bersifat dua dimensional, tiga dimensional, pencampuran, atau perluasannya untuk seolah-olah menjadi hidup dan menentukan keadaan makna yang dikandungnya secara berkembang.

"The essential norms or conventions of painting are at the same time the limiting conditions with which a picture must comply in order to be experienced as a picture. Modernism has found that these limits can be pushed back indefinitely - before a picture stops being a picture and turns into an arbitrary object; but it has also found that the further back these limits are pushed the more explicitly they have to be observed and 
indicated"(Greenberg, 1995).

Seni lukis selain memiliki nilai historisnya sendiri namun seiring perkembangannya juga mengalami ekspansi medium, seperti yang sudah tertulis.

\section{Gagasan Karya}

Transformasi material kertas adalah upaya penulis meyakini ihwal melihat, yang memang bukan soal yang sederhana karena cara kita melihat seseorang atau benda-benda dipengaruhi oleh apa yang kita ketahui atau yang kita percayai. Objek yang merupakan simbol pada sebuah karya seni rupa tentunya tidak jadi bermakna hanya karena sedang menunjukkan artinya secara tertentu saja, melainkan karena simbol tersebut ada dalam suatu keadaan yang diwakili oleh kualitas material yang menyusun karya tersebut. Materialitas karya seni tersebutlah yang menandakan soal yang-lain, menjadi ibarat, tentang sesuatu hal dengan membawa serta konteks sebuah benda. Soal kualitas secara kebendaan suatu benda, sebagaimana yang dimaksud Heidegger, tentu tidak berarti adalah tentang benda itu sendiri melainkan soal kualitas nilai kebendaan (thingness) yang juga hadir dan ada di luar benda itu sendiri (Heidegger, 1998).

Saat memandang sebuah benda penulis perlu melihat benda dengan selalu melihat kaitan antara benda-benda itu dengan diri sendiri karena cara memandang seseorang selalu berada dalam pergerakan yang terus berubah-ubah dan berusaha secara terus menerus untuk mengira-ngira benda-benda yang terlihat itu sebagaimana juga cara seseorang untuk memahami dirinya sendiri yang terus berubah-ubah.

Melihat sisi lain dari lukisan dengan cara menyiasatinya menggunakan sudut pandang kebendaan (a thingly quality) serta menyikapi keruangan, penulis menyadari persoalan keruangan dalan seni telah lama menjadi salah satu cara seniman untuk mempresentasikan karyanya. Praktik semacam ini berdekatan dengan apa yang dimaksud dengan seni instalasi. Seni instalasi (Installation Art) adalah istilah yang relatif baru dalam lingkup seni rupa, khususnya pada seni rupa kontemporer. Hanya pada dekade ini, seni instalasi sering digunakan untuk menjelaskan jenis karya seni yang menolak konsentrasi pada satu objek dan lebih cenderung menyukai pertimbangan antar-objek dan konteksnya. Lucio Fontana pernah menuliskan gagasannya tentang keruangan dalam buku berjudul "Installation Art" tahun 1996 mengenai kesadaran ruang yang menjadi salah satu penyebab munculnya karya-karya bersifat instalatif. Spatialism (keruangan) menurut Lucio mempersoalkan tentang Spacialismo atau konsep-konsep spasial. Spatialism bertujuan untuk mengangkat ruang ilusif pada karya-karya konvensional dan menyatukan seni dengan arsitektur dan lingkungan yang lebih luas (Mills, 2009).

Pemikiran ruang yang lebih luas juga sampai pada kesadaran tentang realitas batas antara karya dan masuknya konteks lingkungan dalam realitas karya. Bahwa seni lukis tidak seharusnya dibatasi oleh bingkai (frame) dan tidak terbatas dengan bentuk-bentuk yang normatif. Karyakarya yang dihadirkan oleh penulis adalah soal pengaturan transformasi terhadap material menjadi sebuah objek atau artefak melalui pendeketan proses penciptaan karya seni lukis. Dengan tindakan otoritasnya penulis berupaya mengkaitkan pendekatannya kepada keruangan dan segala kemungkinannya yang tidak terbatas, sehingga karya-karyanya dapat terkonsentrasi dan memungkinkan untuk penikmat seni berada di antara objek dan masuk ke dalam relasi antar objek dan ruang. Penikmat seni dalam hal ini secara fisik dapat langsung aktif berada dalam karya. Penulis mencoba menggabungkan berbagai unsur pendekatan kekaryaannya untuk dapat memberikan konteks keruangan dan kehadiran medium ke dalam olahan karya seninya.

\section{Konsep Visual}

Konsep Visual menentukan bagaimana sebuah gagasan atau ide hendak ditampilkan dalam sebuah karya dan diterjemahkan secara visual. Tema 
yang memiliki judul "Transformasi Material Dalam Penciptaan Karya Seni" akan berusaha diwujudkan kedalam Bahasa visual. Dalam bagian ini akan diuraikan berbagai hal yang berkaitan dengan usahausaha untuk menampilkan gagasan atau ide yang ingin disampaikan oleh penulis kedalam bahasa visual melalui karya seni berbahan dasar kertas.

Pada tahapan awal dilakukan pengamatan-pengamatan yang berkaitan dengan material itu sendiri, yaitu kertas yang telah ditansformasikan menjadi media berkarya penulis. Bagaimana kertas dapat dieksplorasi untuk menghadirkan sensasi persoalan materialitas. Materialitas yang dimaksud adalah cara memandang dan membawa pemahaman terhadap rupa bahan, memanfaatkan material adalah usaha menegaskan keintiman seniman terhadap material yang digunakan serta sebagai cara meraba sifat-sifat khas suatu bahan melalui penginderaan. Dalam kajian estetika, terdapat pandangan yang sifatnya instrumental untuk mengkaji pandangan secara filosofis bagaimana dan sejauh mana fungsi medium berjalan, serta bagaimana secara signifikan mempengaruhi pemahaman atau apresiasi terhadap seni. Melihat medium tidak esensial bagi keberadaan dan apresiasi terhadap karya.

Hal ini mencermati bahwa faktor ekspresi artistik terletak pada dimensi internal seniman, sedangkan kerja seniman pada medium dibedakan antara kerja seni dan kerja kriya (Craft). Seni bagi penulis adalah kerja konsepsi, konsepsi yang dimaksud persoalan eksekusi karya merupakan dimensi ektsternal atau keterampilan (craft involved).

Penulis melihat signifikasi medium terhadap keberadaan dan apresiasi terhadap karya: proses reka bentuk dalam proses kreatif merupakan bagian penting dalam melihat nilai sebuah karya. Dimensi ini melihat media sebagai "objek estetik" (aesthetic object) yang memungkinkan menjadi wilayah untuk merasakan pengalaman secara langsung melalui penginderaan. Bagaimanapun karya - karya penulis tetap menggunakan konsep - konsep dasar seni lukis namun dengan pendekatan yang berbeda. Perbedaan ini ialah pada persoalan dimensi keruangan dan kehadiran medium (space and presentness) dan kualitas kebendaan (a quality thingly) yang bertujuan untuk membangkitkan sensasi serta menghadirkan sebuah narasi melalui transformasi terhadap material yang dapat memperlihatkan perubahan sifat, bentuk dan konteks yang terkandung di dalamnya hingga menjadi sebuah karya seni. Karya - karya diciptakan mengunakan bahanbahan alternatif untuk menggantikan cat, kanvas, kayu, batu, logam, porselen,serat kaca, yang sering dibilang lebih 'abadi'.

Dalam buku Medium in Art, Joseph Margolis (Davies, 2003) istilah medium menjadi dua, yaitu medium fisik (physical medium) dan medium artistik (artistic medium). Sebagai contoh seni lukis, medium fisik terdiri dari pigmen cat minyak, cat air, tempera yang diaplikasikan pada kanvas atau panil, sedangkan medium artistik adalah "tujuan dan teknis" tertentu seperti kualitas sapuan kuas (brush strokes). Dengan kata lain dalam melihat medium lukis tidak bisa hanya melihat aspek fisiknya saja (cat dan kanvas), namun juga cara spesifik seniman saat bekerja pada medium fisiknya. Medium dalam konteks ini menghasilkan kode kode estetik spesifik yang diproduksi oleh penulis, berkaitan dengan itensi dan pengetahuan penulis dalam mengolah material yang digunakan. Pada pendekatan persoalan pembagian medium dalam seni lukis tersebut penulis mencoba menerapkan dalam proses perwujudan karya. Medium fisik (physical medium) terdiri dari material atau bahanbahan yang digunakan selama proses perwujudan sebuah karya seni yang telah diciptakan, penulis memanfaatkan bahanbahan tersebut untuk ditransformasikan dan diolah menjadi satu kesatuan dengan tujuan merekayasa bentuk dan memanfaatkan kekhasan bahan serta sifatsifatnya.

Penulis menyadari pemilihan bahan yang digunakan memiliki kode-kode estetiknya sendiri. Hal ini disebabkan 
karena kode-kode ini berkaitan dengan konteks dari bahan tersebut, sehingga memungkinkan untuk terjadinya negosiasi makna. Kode ini juga bersifat ekspresif, menjangkau dunia subjektif (penulis), oleh karena itu cenderung menjadi sumber "kesenangan" dan bermakna bagi dunianya sendiri.

Penulis menggunakan kertas yang diciptakan sendiri untuk menciptakan karya seninya. Pemilihan cara tersebut bertujuan mencari segala kemungkinan dan memanfaatkan kertas diluar fungsi utamanya secara konvensional atau biasanya menjadi pilihan seniman secara umum untuk dijadikan medium berkarya. Sehingga fungsi dan sifat kertas telah mengalami pergeseran dari yang seharusnya. Kertas memiliki keindahan yang khas jika dibandingkan dengan media lainnya. Keindahan tersebut tampak pada kehalusan atau kekasaran tekstur, ketebalan atau ketipisan, sifat transparan, bentuk dan ukuran, warna, volume dan serat, serta karakter kelenturannya. Kualitas bahan dasar (raw material), teknik pengolahan bahan menjadi bubur kertas, serta peralatan yang dipakai untuk menyaring dan membentuk kertas berperan menentukan kualitas potensi estetik yag menyertai helaian kertas itu sendiri, semua itu dapat dikendalikan oleh penulis ketika melakukan proses perwujudan menggunakan teknik pembuatan kertas olahannya sehingga penulis dapat merekayasa kertas dalam berinovasi terhadap kebebasan pemilihan medium untuk karya seninya.

Pemilihan bahan dan teknik ini selalu memunculkan cara baru untuk bereksplorasi. Misalnya, kertas dapat dilebur, digabungkan, disusun dan diolah menjadi satu kesatuan sehingga potensi kertas tidak terbatas. Kini ekspresi seni rupa kontemporer yang memanfaatkan kertas kian beragam, mulai dari ekspresi dua dimensi hingga tiga dimensi, dan dengan berbagai istilah, seperti patung, objek dan instalasi. Melalui eskpresi pada atau dengan kertas, tema-tema pengalaman manusia dalam kehidupannya dapat dicurahkan dengan memanfaatkan potensi artistik yang melekat pada kertas. Dimensi sains, teknologi, seni dan budaya, bahkan spiritiual menjadi satu kesatuan dalam karya seni berbasis kertas.

\section{Proses Penciptaan}

Preparation merupakan tahapan untuk menyiapkan segala kebutuhan untuk membuat karya. Salah satunya yaitu rancangan sketsa, dalam tahap ini rancangan yang dilakukan lebih terfokus kepada struktur karya yang ingin diciptakan, dikarenakan pendekatan visual dari karya penulis memiliki kecenderungan kepada bentuk-bentuk geometris dan minimalis sehingga rancangan yang dibuat mengacu kepada bentuk-bentuk dasar dan kerangka atau struktur dari karya, karya kertas penulis cenderung memiliki lapisan, ketebalan dan tumpukan yang harus dipertimbangkan dengan tepat agar tidak terjadi kesalahan ketika proses penyusunan berlangsung. Misalnya mengambil struktur dari kerdus atau cardboard yang memiliki struktur berlapis untuk menahan beban mati (dead load) untuk keperluan memproteksi tekanan objek didalamnya dari luar.

Tahap pembentukan kertas meliputi mencetak dan menyaring, keduanya memiliki cara yang beragam sesuai kebutuhan. Yang membedakan adalah teknik dan alat yang digunakan, untuk karya yang dijelaskan ini menggunakan cara mencetak menggunakan botol yang memiliki corong berlubang, yang dimasuki bubur kertas untuk membentuk pola jaring berulang dan acak di atas kain flannel atau kain felt. Proses penyaringan berlangsung secara langsung ketika kain menyerap kadar air pada bubur kertas, keuntungan lainnya adalah bahwa kain memiliki fleksibilitas yang baik dalam mebentuk objek. Dengan kelebihan tersebut penulis dapat merekayasa bentuk-bentuk menggunakan alat-alat di sekitar untuk menciptakan karya yang melengkung supaya mendapatkan dimensi karya yang beragam. Setelah semua tahapan sebelumnya selesai, evaluasi 
secara keseluruhan dilakukan. Hal ini untuk mengurangi dan menambahkan halhal yang dirasa kurang sesusai, sekaligus sebagai pembelajaran dari hasil eksplorasi yang sudah selesai; pengalaman tersebut ditambahkan pada proses karya selanjutnya untuk meminimalisasi kesalahan penulis dalam proses perwujudan. Setelah itu karya yang sudah selesai dilapisi dengan varnish untuk memberikan perlindungan tambahan jangka panjang.

\section{Deskripsi Karya}

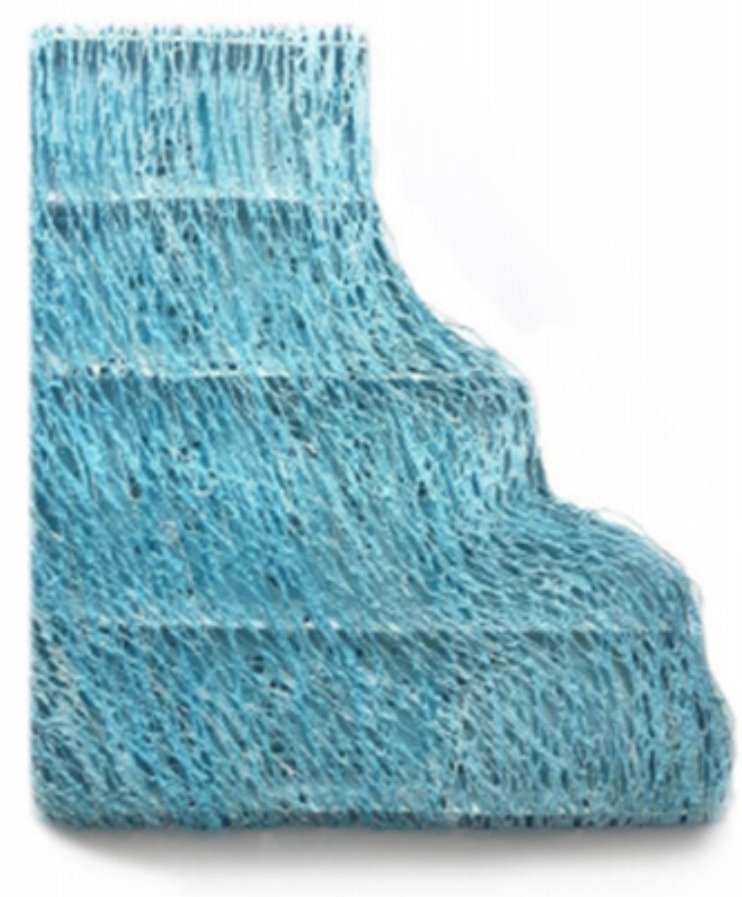

Gambar 1 "Surface Liner", 2020

Pigmented Handmade Paper, $60 \mathrm{~cm} \times 70 \mathrm{~cm}$ (Sumber: Dok. Widi Pangestu Sugiono)

Karya ini mengeskplorasi sifat kertas yang tipis dengan membentuk pola acak seperti seutas benang yang dirajut dan lapisan struktur dengan bentuk geometris yang sisinya terdapat lengkungan. Penggabungan ini tanpa menggunakan perekat dengan teknis seperti kolase yang mengabungkan berbagai bentuk untuk menjadi satu bagian komposisi. Garis horizontal yang terlihat adalah penyangga lapisan terluar kertas, tujuannya untuk membetuk dimensi dan memberikan jarak dari permukaan atas. Seperti karya lainnya bayangan menjadi bagian dari komposisi imajiner yang terbentuk dari celah-celah pola acak pada permukaan, eksplorasi ini bertujuan untuk menciptakan bentuk yang dinamis dengan memanfaatkan ketipisan kertas namun dapat menimbulkan keruangan yang dikombinasikan dengan

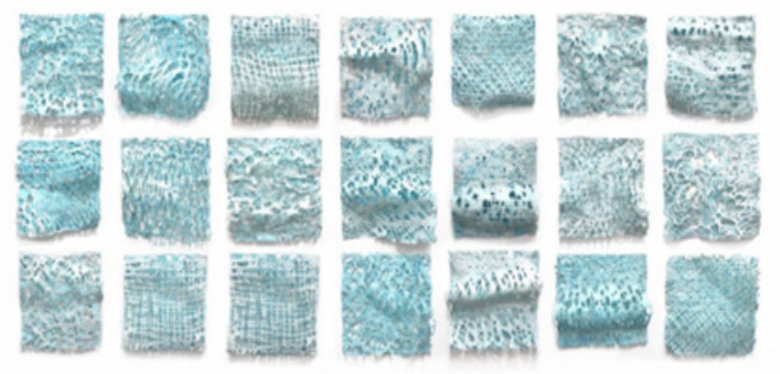

Gambar 2 Tesselllation Field", 2020

Pigmented Handmade Paper, $20 \mathrm{~cm}$ x $20 \mathrm{~cm}$

(21 panels). (Sumber: Dok. Munif)

warna biru yang tercampur dengan putih menciptakan detail yang terlihat abstrak secara visual.

Karya ini berjumlah 21 panel yang disusun secara horizontal membentuk barik-barik pada bidang kosongnya, karya ini menggunakan penggayaan abstrak dengan komposisi yang berbeda setiap panelnya. Terinspirasi dari pola yang berada dari alam (pattern in nature) pola yang seara konteks berbeda dengan satu dan lainnya ini terkadang muncul dari perhitungan secara matematis. Sejak Yunani Kuno, para filsuf mencoba untuk menemukan jawaban dari pola yang secara alami ini terbentuk, mulai dari Plato, Phytagoras, hingga Empedocies pun mempertanyakan hal yang sama.

Keberagam pola ini dapat ditemukan di berbagai elemen bumi, seperti bentuk simetris, spiral, gelombang, garis, teselasi, cekungan dan retakan. Melihat dari berbagai macam pola tersebut material kertas memiliki kemampuan untuk merekayasa seluruh pola alam melalui sifat fleksibilitas kertas untuk menghasilkan pola pola yang dinginkan, merekayasa pola dan membentuknya 
dengan lapisan lain untuk menghadirkan dimensi karya yang beragam. Harmonisasi bentuk dan komposisi secara abstrak dapat dirasakan melalui pengamatan terhadap karya ini, keleluasaan untuk memfokuskan terhadap pola yang terlihat lebih memiliki daya pikat adalah sesuatu yang sah, secara tidak langsung pola-pola ini akan memperlihatkan keintimannya dengan penikmat terhadap kedekatan dan pengalaman estetisnya melihat secara langsung pola-pola yang ada di alam. Bagi penulis mengolah presepsi adalah salah satu dari kebanyakan cara untuk memperlihatkan materialitas terhadap karya, bagaimana kode-kode estetik dapat membentuk realitasnya terhadap objek.

\section{Kesimpulan}

Semangat eksperimentasi terhadap kerja kreatif dalam proses pengerjaan Laporan Tugas Akhir dan 20 karya di dalamnya, banyak pembelajaran yang didapat di setiap prosesnya. Ketika tahap awal memulai perencanaan dan pendalaman konsep ide penulis menyadari bahwa konsep untuk karya seninya adalah keintemannya selama ini dengan material, yaitu kertas. Kertas dengan pencapain artistiknya serta makna yang terkadung di dalamnya menghadirkan pengalaman memandang dan mengenali materialitas dan rupa bahan. Materi itu akan muncul sebagai sensasi, sensasi bagi penulis adalah upaya untuk menhadirkan penginderaan, soal rasamerasa atau mempresepsi sesuatu melalui kompleksitas penginderaan. Sehingga penulis merasa tidak diperlukannya narasi yang berhubungan dengan keadaaan ataupun tematik yang bisa dibaca secara harafiah melalui karya seninya. Dengan memperlihatkan materialitas dan rupa bahan penulis berusaha untuk memberikan cara lain memandang yang tidak hanya terpuaskan oleh banyaknya informasi atau pesan tertentu melainkan dengan menggugahkan kepekaan dan menantang cara meraba sfat- sifat khas suatu bahan melalui mata.

Dari 20 karya kertas yang telah dibuat, bebrapa karya dianggap sudah mewakili maksud yang ingin di sampaikan secara konsep penciptaan dan perwujudan, namun ada sebagian yang perlu kembali dicermati subtansinya dan persoalan materialitasnya, karya "Predictable Manner: Fractal" merupakan karya awal dan merupakan percobaan penggunaan efek dengan permainan pigmen dan bubur kertas secara spontan, walupun menghadirkan visual yang menarik namun karya tersebut tidak mampu memperlihatkan sisi materialitas yang dimaksud, karena sifatnya yang datar (flatness) tanpa permainan dimensi dan tekstur yang terlalu halus. Karya "Triple Wall Corugated" dan "Tessellation Field" dianggap telah berhasil mewakili gagasan yang penulis inginkan, terlihat dari kekhasan rupa bahan yang menonjol serta permainan dimensi dan cahaya berhasil memenuhi ekspetasi visual dari penulis.

Penulis menyadari karya seni bagaimanapun akan selalu dinikmati ketika hasil akhirnya terlihat secara visual. Namun bagi penulis, penciptaan seorang seniman seharusnya dipahami sebagai satu bagian saja dari pencarian yang lebih panjang dan esensial. Kertas membawa penulis menuju penghayatan yang mendalam terhadap dirinya dan telah membentuk cara pandang baru terhadap kertas, penulis tidak memperlakukan kertas sebagai material belaka, melainkan sebagai medium sekaligus idiom yang diharapkan mampu untuk terus berkembang, bukan saja sebagai eksperimentasi artistik namun akan berangsur-angsur menjadi kompleks dan pada akhirnya penghayatan filosofis terhadap kertas. Hal tersebut menjadi motivasi untuk terus bereksplorasi terhadap rupa bahan, salah satunya kertas sebagai bentuk pembelajaran terhadap material dengan harapan penulis dapat memperkarya ragam visual seni kertas dalam medan seni rupa kontemporer.

Karya-karya yang dihasilkan selama proses pengerjaan ini dirasa dapat mewakili konsep tentang "Transformasi Material Dalam Penciptaan Karya Seni Lukis". Semua karya dihasilkan dengan 
usaha dan kerja keras serta keseriusan untuk menampilkan pengetahuan secara akademis yang dipelajari selama berkuliah di jurusan Seni Murni ISI Yogyakarta. Melalui jurnal ini diharapkan mampu menjadi bermanfaat sebagai inspirasi ide konsep penciptaan serta konsep perwujudan bagi mahasiswa seni lainnya dan masyarakat umum.

\section{Kepustakaan}

Davies, D. (2003). Medium in art. The Oxford Handbook of Aesthetics, 181-191.

Greenberg, C. (1995). The Collected Essays and Criticism, Volume 4: Modernism with a Vengeance, 1957-1969 (Vol. 4). University of Chicago Press.

Heidegger, M. (1998). The Origin of The Work of Art. Oxford University Press.

McLuhan, M., \& MCLUHAN, M. A. (1994). Understanding media:

The extensions of man. MIT press.

Mills, C. M. (2009). Materiality as the basis for the aesthetic experience in contemporary art. The University of Montana. 